\title{
States of Disturbance: Representation of Adolescence and Politics in Rüta Mežavilka's Dzimuši Latvijai and Kathrin Aehnlich's Wenn ich groß bin, flieg ich zu den Sternen ${ }^{1}$
}

\author{
OLGA BAZILEVIČA
}

\begin{abstract}
In the following article, the correlation between the representation of adolescence and political reality in memory fiction will be analysed using the example of two novels: Rūta Mežavilka's Latvian novel Dzimuši Latvijai (Born for Latvia) and Wenn ich groß bin, flieg ich zu den Sternen (When I Grow Up I Will Fly To The Stars) by the German author Kathrin Aehnlich. The link between politics and adolescence that is created in these novels becomes a means to normalize the representation of the socialist past in the official memory culture of Latvia and of Germany. Key to such an interpretation is a differentiated understanding of adolescence as a productive crisis: a period of transformation and disruption as well as creation of new versions of reality. Through the introduction of adolescence as a time of transgression against the ruling system, the novels put the simple distinction where East is associated with socialism and negatively equated to totalitarianism whereas the West and capitalism are positively linked to democracy. The images created in the novels run against the official memory cultures into which they are inscribed and are part of a new counter-memory, despite their geographic and temporal differences.
\end{abstract}

Keywords: Adolescence, Germany, Latvia, Representation of Socialism, Memory Cultures, Gender

Adolescence is a time of breaks - be it the cracking voice, a sudden change in taste or the constant wish to go against the will of one's parents and teachers. ${ }^{2}$ As a stage of life, adolescence is mostly seen as a transitory time, a step towards adulthood - adolescents are invited to participate in certain areas of the social

1 Olga Bazileviča's research is funded by German Academic Exchange Service (DAAD).

2 In this paper, adolescence is understood as a "psychological coping with the bodily and sexual maturing" (Remschmidt 1992: 2) and is not to be confused with puberty which describes solely the physiological changes that the transformation from childhood into adulthood causes.

DOI: http://dx.doi.org/10.12697/IL.2015.20.1.14 
life and are given more responsibilities and tasks preparing them to become a 'full member' of the society. ${ }^{3}$ Yet adolescents remain in-between - while they still enjoy (partial) support from adults and thus carry a lower burden of obligations, their freedom is nevertheless controlled and their possibilities limited. As opposed to childhood, which since Rousseau is seen as a 'golden age' of blissful goodness, purity, and innocence, adolescence within contemporary Western culture is perceived as a disturbing and disruptive stage of life. Carsten Gansel, for example, connects adolescence to the category of Störung (German for 'disturbance', 'disruption', but also 'dysfunction' or 'disorder'). As a phase of "border crossing", adolescence is by and large seen in a socially negative light as the borders that are transgressed are those of the institutions that constitute society itself. Adolescent Störungen thus are considered "risky in their different destructive potentials“4 (Gansel 2013: 33). While traditional establishments are invested in the maintenance of the status-quo, disruptions of settled systems can also be extremely productive and liberating, especially in cases of hegemonic political and cultural institutions. Taking the role of adolescent youth in progressive political movements and cultural experiments into account, Gansel rightfully pleas for a wider, more constructive and productive understanding of Störung as a cultural category that would do justice to the creative potential of "disruptive border crossings". ${ }^{5}$ For a more differentiated analysis of the category in cultural texts, Gansel suggests a distinction between three stages of Störung:

a) „Aufstörung“ - arousing attention, open to integration and restitution.

b) "Verstörung“ - a profound irritation, open to repair and regeneration.

c) „Zerstörung“ - a sustainable overthrow, unrepairable and irreversible.

(Gansel 2013: 35)

I will draw a parallel between the representations of adolescence and political realities in memory fiction using the example of two novels: Rūta Mežavilka's

3 For a long time, adolescence has been reduced to the sheer transformation from childhood to adulthood, which made it hardly possible to account for the positive aspects of this life phase as well as deal with the adolescent crises productively. Even though adolescence has been consequently accepted as a separate phase of life in the last decades, it is still often perceived pejoratively in the society. For an introduction of different understanding of adolescent and a brief history of adolescence in Europe, see Remschmidt 1992.

4 Here and further, all translations from German and Latvian are done by the author.

5 Störung is by no means a category that is reduced to the context of adolescence, but can be applied to any process of border crossing which results in a disruption of a given system. For more on the category of Störung, see Gansel \& Ächtler 2013. 
Latvian novel Dzimuši Latvijai (Born for Latvia) and Wenn ich groß bin, flieg ich zu den Sternen (When I Grow Up I Will Fly To The Stars) by the German author Kathrin Aehnlich. I argue that in these texts, the link between politics and adolescence works as a means to normalize the central narrative of the socialist past in the official memory culture ${ }^{6}$ of Latvia and of Germany. This furthermore underlines the manner in which a heroic vision of the socialist past is undercut through the thematic and narrative link that is established between politics and adolescence. ${ }^{7}$ Key to such an interpretation implies a differentiated understanding of adolescence as a productive crisis: a period of transformation and disruption as well as of the creation of new versions of reality. ${ }^{8}$

Both Dzimuši Latvijai and Wenn ich groß bin are set in socialist states - Soviet Latvia and the GDR respectively - with Dzimuši Latvijai set several decades later than in Wenn ich groß bin. While these temporal and geographical differences constitute a substantial discrepancy ${ }^{9}$, the novels can nevertheless be compared in the way in which they represent their respective historical realities. Whereas the comparison of a particular event or concept (such as WWII, the Prague Spring or the fall of the Berlin Wall) described in a Latvian and a German novel may require a consideration of the differentiated historical and social context this is not

6 Memory culture is used in the present paper as "a loose umbrella term for the entirety of the not specifically scientific use of the history for the public" (Troebst 2006:26). For an overview of the political functions of memory culture, see (Jarausch 2002). For the response to the ongoing criticism of the term by Aleida Assmann, one of the leading scholars in studies of collective memory, see her latest book (Assmann 2013).

7 A representation of the socialist past in German and Latvian memory cultures can only be briefly sketched out in this article. For detailed analysis of the representation of the GDR in the memory culture of Germany see, amongst others, Assmann 2013, Mühlberg 2002, Rechtien \& Tate 2011. For further information on Latvia's memory culture, see Pettai 2011. Comparative aspects of different models of remembering the socialist past are touched upon in Jarausch \& Sabrow 2002, Rathkolb \& Sooman 2011.

8 Other potential points of comparison between these two works include gender roles and their connection to socialism or capitalism. While a depiction of socialist reality and the use of humour as a powerful tool in the de-demonification of the socialist past will be briefly considered in the present article, it deserves a more detailed analysis.

9 These discrepancies occur on several levels. First, the socialist state in the GDR and LSSR was established and run on very different terms. Latvia was occupied by the Soviet army, annexed to the Soviet Union and largely ruled by non-Latvian Soviet functionaries. Thousands of Latvians became victims to repressions during Stalin's rule and were systematically discriminated culturally and politically during the Soviet period. GDR was established and run under the control of Soviet Centre, yet by Germans themselves. This means a different understanding of the victim-perpetrator roles (Zake 2011:107). Second, the socialist past is remembered differently - a point that will be touched upon briefly in the present article. 
necessary for an analysis that focuses on the devices and tropes of representation of historical reality. I will first focus on the poetics through which adolescence is conjoined to the political sphere in these novels, and thus primarily consider a reading of the novels' texture rather than its value as a witness of historical events. Then, the article seeks to explore the ways in which the analyzed novels intersect with the memory cultures part of which they are. In other words, the official representation of the socialist past in the society and not the historical truth itself is of interest for the following analysis. I argue that adolescence works as a metaphor for a productive crisis in these novels and is a key element for creation of an alternative to the mainstream narrative. The focus of the article lies in the esthetics of representation of the past and the possibilities of its productive disruption, and I suggest that the concept of an adolescent Störung can be productively applied across cultures through an analysis of narratives set in temporally and geographically distinct climes.

Published in 2013, Dzimuši Latvijai is the first novel by the young Latvian author Rūta Mežavilka. Crucial for an understanding of the novel is its narrative structure: the text is organized in fragments that constitute two separate narrative strands (referred to as 'Level 1' and 'Level 2' in the following analysis). On Level 1, a third-person narrator recounts a single day (in March 2005) in the life of the protagonist, Anna whereas on Level 2, an adolescent first-person narrator details the story of her first love in Riga between 1987 and 1990. Through characters that appear on both levels, the protagonist of Level 1 can be identified as the future self of the first-person narrator of Level 2. The narrative turns upon a short encounter between Anna and Andrejs on Level 1 that triggers the emergence of the Level 2 narrative. The story of their relationship is recounted by the first-person narrator on Level 2; her story can be clearly understood as the Level 1 protagonist's field memories. ${ }^{10}$ The historical events that constitute the background of the narrative on the Level 2 in Dzimuši Latvijai depict one of the most important moments in the history of modern Latvia - the beginning of the so-called treša Atmoda ('Third Awakening'), a social and political move-

10 The distinction between field and observer memories was first suggested by the psychologists Georgia Nigro and Ulric Neisser in 1983. They discovered that human memories can be categorised according to the point of view of the remembering subject. In case of field memories one remembers oneself embodying the remembered self; if the remembering subject sees the remembered self as a separated subject, her memories are described as observer memories. The protagonist of the Level 1 of Dzimuši Latvijai refuses to accept her past as part of her present and consciously suppresses her memories. The absence of observer memories and thus of reflection on the mechanisms of remembering supports the wish to separate the past from the future on the level of structure. 
ment, which resulted in the renewed Latvian independence of 1991. The text revolves around the personal lives of the characters, being tightly bound to the concurrent historical events, and is best illustrated by the title of the novel - the characters are literally "Born for Latvia." The title is, however, ironic - the heroic representation of Atmoda and the pathos of the movement that is linked to assumptions that individuals are born for their states, is contested in Mežavilka's novel. An example of this can be seen in the manner in which the book considers the historical events of 1988 through the description of a Latvian flag, or rather of something that could have become a flag: "I open the drawer. In there, between crumpled t-shirts and panties lie bent cloth bands - dark red and white. The flag. I had an idea to sew my own. So that our family has its own flag. In that summer, many sew their flags. [...] I never finished my flag" (DL 12-13). Lying amid slovenly underwear, the state symbol loses its traditionally exalted meaning and is reduced to pieces of cloth, a symbol of teenage sloppiness and forgetfulness. The very introduction of the state of Latvia, symbolized by the red-white-red flag, is portrayed as ironic, going against the official depiction of Atmoda. Paradigmatic for the representation of these events in Latvian official memory culture are the words of Dainis İvans, one of the leaders of the movement. In his speech at a conference dedicated to the $25^{\text {th }}$ anniversary of the founding of Latvijas Tautas Fronte (the Latvian People's Front) ${ }^{11}$, he claimed that "One can become disappointed in everything, but one cannot be disappointed in Atmoda. We are a land chosen by God and people chosen by God, just like our brother Lithuanians and Estonians" (Delfi.lv). 27 years after the beginning of the movement, and 23 years after the recovery of independence, Atmoda is seen as a sacred moment in the history of the country and its people; for İvāns it cannot be disappointing, it cannot be seen critically. While other social or political developments can be upsetting, Atmoda should remain untouchable.

The metaphor of awakening suggests a passive before-state, a sleep that has to end, a nightmare that is terminated. Once awakened, the traces of sleep fade with time or are erased so that real life can begin. An awakening can be seen as an absolute change of state, a clear border - one cannot be sleeping and

11 Latvijas Tautas Fronte (LTF) was one of the key players on the political arena between 1987 and 1991. An organisation with more than 250000 members, it first demanded for reforms and more autonomy for the Latvian Socialist Soviet Republic (LSSR). It did, however, soon change its demands to complete independence of Latvia. The importance of LTF which became one of the most important symbols of Atmoda in the memory culture of Latvia is at best demonstrated by the large of scope of celebratory events to commemorate the $25^{\text {th }}$ anniversary of its foundation. It included a series of public events, conferences, concerts and exhibition and received high level of media attention. 
awake at the same time, the past and the present are thus separated and their co-existence is not possible. Such an understanding of "awakening" goes hand in hand with the image of the independence movement in the public memory culture and, to a large extend, in Latvian historiography. The 50 years of the Soviet rule are seen as a lapse, a tragic slip of fate, a forced depart; the refusal to include the five decades of state's and people's history into the self-definition of Latvia and Latvians is best illustrated by the fact that in 1991 the parliament claimed continuity with the Republic of Latvia founded in 1918. This means that independence was not acquired but recovered; the 50 years between 1940 and 1991 are seen as an illegal occupation and annexation by a foreign force. This interpretation of $20^{\text {th }}$-century Latvian history does, however, leave very limited space for the understanding of everyday life during the krievu laiki ('Russian times') as well as of the cultural continuity between different generations. While it cannot be denied that Latvia was illegally occupied in 1941 and that its peoples and resources were harassed by the central government of the USSR for decades, it is also true that they continued to have everyday lives under the regime. They were born and socialized in the LSSR (Latvian Soviet Socialist Republic), and it cannot be assumed that the rules by which they had to live defined their everyday life less than the 'Latvian legacy' of the interwar had previously defined their lives. The history of everyday culture of Soviet Latvia constitutes a research gap that is being only slowly filled by works of Latvian scholars. As Elena Zubkova notices, the mainstream of Latvian historiography - and I would add, of memory culture too - is concentrated on the "key" events of the "victim narrative" of Latvian peoples (Zubkova 2011: 91). Jānis Stradiñš, the editor in chief of the monumental collection of essays Latvieši un Latvia (Latvians and Latvia), admits that the editorial board faced difficulties in obtaining articles dealing with the everyday life in Soviet Union, as well as practices of adaptation and collaboration which he interprets as a unwillingness of Latvian historians to deal with "such painful topics" (Stradiñ̌̌ 2014: 20). Mežavilka's novel takes a very different stand regarding the metaphor of awakening. The text begins with the Level 1 protagonist's physical awakening: "She wanted to go to the sea. She woke up with that vague queasy feeling that she has to go somewhere and do something, otherwise something important will be missed" (DL 7). In this instance, awakening reflects a complete change, yet it is uncertain, illogical and rather unpleasant. The result of the awakening is a "vague" urge to change one's position without a clear aim. If we transpose this image onto the metaphorical awakening of Latvia, the scene suggests a criticism of the positivistic representation of Atmoda as an erratic process driven as much by emotion and the wish for change as it is driven by the pure desire for change merely for the sake of change. 
Both of the described trends of the representation of Latvia's latest past in its official memory culture - the sacralisation and idealization of Atmoda and failure to accept the 50 years of Soviet history as part of nation's history rather than a deviation from the actual course - are also contested on Level 2 in Mežavilka's novel, at the core of which lies the depiction of the everyday life of 'simple people' and a rather sober representation of Atmoda. The intense political developments that constitute the background of the narration only emphasize the fact that even though politics influence the lives of the characters, they do not constitute or devour them completely. On the contrary, the individuals and their relationships stand at the centre of the narrative. Such a representation of Atmoda dedemonizes the Soviet past and humanizes the movement in a detour from the mainstream narrative, opposing the heroic representation of the movement with a more ironic one.

Adolescence works both as a cultural category and a metaphor in Dzimuši Latvijai: the narrated time of Level 2 recounts the three years following the first person narrators coming of age at 16 . This life-changing period of physical and psychic transformations correlates with the fundamental upheavals that occur within the state in which she lives. Her personal rebellion coincides with the Störungen as a major part of the society voices their unwillingness to submit to the state and to the soviet system. It is also remarkable that even though some adult characters voice nationalist or anti-Russian (as well as pro-Latvian) statements, most of the politically loaded comments are voiced by adolescents. For the adolescent characters, the independence movement represents the possibility of a rebellion against their parents and teachers as well as against the world in which they live. Given that their world is defined by Soviet society and the soviet state, their rebellion turns against it too. It is the act of rebellion itself, the risk and the appeal of the prohibited that mostly interests the adolescents - their political motivations are secondary. In describing her favourite places in Riga, the first-person narrator illustrates the manner in which her political rebellion is secondary to her adolescent rebellion:

Plan, ${ }^{12}$ is considered the coolest place, it's chock-full in the afternoons, finding a free table is impossible [...] Planii is always swarming with people, a spirit of rebellion that has never been put into words reigns here - a special subtext of protest can be felt in the looks or in the tone of voice; all kinds of artists [...] come here, they are wearing self-made and self-painted clothes and look deadly stylish. (DL 36)

12 „Plaņi” is a colloquial version of "Planetārijs" ("Planetarium”), the building that housed the described café. 
Here, words like "rebellion", "protest", "coolness" and "style" are used as synonyms; the details of the protest are rendered irrelevant while the clothes of the young people are carefully described, their political agenda is not thematized. In so far as the "spirit of rebellion" has not been "put into words" and demands no explanation, the protest may exist as a mere performance without any actual agenda.

The adolescent narrator goes to illegal movie screenings, sings in an underground band and takes part in a festival called "Rock for Democracy" where she drinks “To Free Latvia!” (DL 122); her personal affairs are much more important to her than the political developments in the country. Movie screenings only interest her because of their coolness, music - because of its rebellious power and, most importantly, because her boyfriend plays it. His rebellion, which is directly linked to political resistance, is also one of the reasons for the narrator's interest in him: "In this moment, I already begin to fall in love with him - such a guy, and even playing in a band. Well, almost a band, they haven't had any gigs yet, there is no performance space; they rehearse in a cellar, it is all really forbidden and illegal" (DL 19). Here, again, no explanation is given for the reason the band should be "forbidden and illegal" - similarly to Plani, a rock band functions more as a symbol of political rebellion than as a carrier of an actual political message. Once her romantic relationship ends, so too does her interest in "Free Latvia": she breaks up with Andrejs on October 7, 1988, the day of one of the largest public demonstrations in Soviet Latvia that were followed by the foundation of the LTF. The narrator only joins the demonstration out of a fear of loneliness. Once she arrives at the location of the demonstration, she describes several festively dressed characters that are obviously emotionally moved by the happening, while she herself remains unemotional: "I feel so far and foreign. I shouldn't have come here" (DL 140). Her description of the speeches and demonstration is estranged and ironic: "Everyone applauds. I too, start clapping without thinking. We have learned to do so this summer. One has to sing after the speech. [...] Another speech, another cheer. How accustom we have become to this" (DL 141). The narrator wonders if her boyfriend is present and answers her own question: "It's impossible that the skeptical and ironical Andrejs could eagerly sing folk songs and feel united with the people." (DL 141) Since this demonstration marked the beginning of the 'second stage' of Atmoda and was held at a time of great uncertainty when even the idea of the restored independency was only starting to cautiously emerge, it cannot be the loss of political actuality that leads to the narrator's apathy. The speeches have lost their appeal to the narrator not because they are politically less urgent, but because they are no longer as dangerous and rebellious as before, they have become "familiar." After realizing the impossibility of feeling an emotional bond with 
the crowd or a connection to the speakers, she leaves the venue. Here, political rebellion is only an Aufstörung since it does not mark a significant change in the character and its traces can be easily overlooked once the process has ended. On the other hand, the experience of an unhappy first love is a transgression that reflects Zerstörung - after the disillusion caused by the break up with her first boyfriend, the narrator of Level 2 and the protagonist of Level 1 never again allow emotions to affect their romantic relationships. The degree of emotional and psychic damage is underlined by the attempts of the Level 1 protagonist to suppress her memories (DL 31, 69, 112).

Rebellion against the Soviet Union and pro-independence statements functions as a group-organising mechanism for the adolescents in Dzimuši Latvijai. This is reflected in the manner in which the narrator recall's the twin brother of the first-person narrator suggesting the formation of a political union in the sixth grade "Now we are a gang. Secret gang, he whispered. We will fight against Hidra [a pro-Soviet teacher - O. B.] and all those Russians. Our goal is free Latvia. No one can know about our plans. We will never betray our people” (DL 29). In the next sentence, the 17-years old narrator calls her brother's idea “(k)ids' monkey tricks" and reveals the actual reason for her brother's proposal: he was attracted to her best friend who would become part of the "gang" (DL 29). These episodes illustrate the lack of actual interest in politics on behalf of the narrator as well as the connection between the adolescent rebellion and the political awakening. Another important element of this argument is the fact that the Level 1 narration, which depicts the future adolescent narrator as the grownup protagonist Anna, has a minimal representation of political reality; Anna's disinterest in current national and international developments borders upon ignorance. What is striking, is that the category of "nation" is also completely lacking on Leven 1: while the tension between ethnic Latvians and Russians is important to the Level 2 narration, the word 'Russian' is not mentioned a single time on Level 1. On Level 2, clear borders are set between 'Us' (Latvians) and 'Them' (Russians) (DL 10, 29, 34 etc.), so much so that an interaction between the two worlds seems impossible. An ultimately different image is presented on Level 1: the protagonist is probably pregnant with the child of an ethnic Russian. The political and psychic consequences of this entail a complete erasure of the borders between the ethnicities in so far as Anna, who in her adolescence is clearly marked as 'Latvian'13, can be seen to have abolished these borders on all levels - allowing her body to merge with that of the 'Other' and thus negating his

13 While in the elementary school, she and her twin brother are described as perfect Latvian children (DL 25), her family is ironically dubbed as "good middle class Latvian family" (DL 55) etc. 
Otherness. This, however, remains an assumption: as ethnicity plays no role on Level 1 , such information is never directly provided. The relevant information is offered only indirectly through the Slavic names of certain characters and the description of their physical appearance. This schism between the depiction of nationality on different levels of the narrative in Dzimuši Latvijai is another indication of the link between adolescence and politics. It is striking that the nationalist sentiments that are especially characteristic of such processes as independence movements and state-founding ${ }^{14}$ only apply to the 'adolescence' text and narrative.

The events described on Level 2 clearly represent Zerstörung both for the society that it describes and for the enamored teenage girl who narrates the story: the consequences of these processes are irreversible and final. Her adolescence and the nation's Atmoda are crises that are simultaneously devastating and productive. The depiction of Atmoda as a productive crisis is cardinally different from the perception of Atmoda as a beginning or return to the initial and the only acceptable state or awakening of an independent Latvia that prevails in Latvian official memory culture. As a Störung, Atmoda represents a beginning just as much as it represents an end - the end of Soviet Latvia, the home country of the narrator. Such an understanding of the late 1980's contributes to the dedemonification of the 'Russian times' in Riga: instead of presenting the city as an arena for a political struggle, the narrator creates a series of snapshots of the everyday culture in the city. The streets, buildings, street names, cafés and even their menus are documented in an attempt to (re)construct the remembered city, the city of the protagonist's and of the narrator's youth. Even though metaphors of greyness and claustrophobic crowdedness typical of the description of the socialist reality prevail in the narrative of Level 2 , they are not of an othering quality in so far as the greyness and chaos seem to have changed only partially: Anna's reality in 2005 is often described in similar terms. What has changed, or rather what has disappeared, is the city described on Level 2 - with its cheap

${ }^{14}$ It should be noted that to define Atmoda as a nationalist movement would be oversimplifying. $L T F$, one of its most important agents, was founded as a movement based on civic understanding of nation and thus much more open to Russian-speakers than some of the other parties that were part of Atmoda. For more on the international aspects of $L T F$, see Lazda 2009. It is rather the first seven years of the re-establishment of the independence that was marked by nationalist sentiments in the Latvian society and politics. It is, however, somewhere in the first decade of the reviewed independence that the first-person narrator stops "hating Russians" (DL 157). Since it is not clear, when exactly this change happened to the narrator, it is impossible to say if this happened despite the nationalist setiments in Latvia between 1991-1998 or if she followed the trends that were popular in the society (e.g. changed her mind after 1998). 
cafés for struggling artists and their rebellious flair, the socialist street names and monuments that constituted the city in which the protagonist grew up. The nostalgic - but not naïve - mode of remembering becomes more apparent by the end of the novel. For example, the protagonist describes a family picture from the earlier narrated time of Level 2 as "black and white, young, in the happy bliss of not knowing about the future" (DL 134). In the last entry entitled "Epilogue", she also underlines all the important developments between 1990 and 2005, starting with the disappearance, deconstruction or re-modeling of the objects she has described with scrutiny and that change from open spaces for youth to gated areas for homeless people. She also touches upon the - mostly tragic - fate of some of the characters. Here are only few of the described events:

In the summer 1991 Lenins statue will be torn down and Lenin Street will be again holding the name of Freedom. The name of Têrbata will be returned to Stučka street. [...] The building [of Planetarium] will be given back to church, the café will be liquidated, it will be a temple again. A splendid iron gate will be built around it and no one will sit on the stairs of the cathedral anymore, only a few homeless on the side of the street. [...][A former teacher] will be found stabbed in the summer of 1993 [...] In the fall of the same year, Sirsnina [another teacher] will die of cancer after another surgery. [...] In the fall of 1996 Johanson [a classmate] will be found dead [...] - drug overdose" etc. (DL 156-57, original Italics)

The "Epilogue" thus hardly leaves an impression of an obvious improvement after the watershed events of 1991 - the only positive development is that the narrator "stopped hating Russians" (DL 157) at some point. Rather we are left with a bittersweet feeling of sadness for a time and people gone. However, Atmoda is not only represented as the end on an era, but is important as a process that exposes two qualities that are associated with it - nationalism and emotionality. The grown-up protagonist of Level 1 has learned to leave nationalism behind as a silly adolescent trait, but she has also excluded any emotional attachment and has failed to maintain old, or create new, meaningful relationships with other characters. The heated nationalism of the 18 -years old has been substituted by political ignorance of a 35-year old who no longer believes in love. Thus, adolescence and Atmoda are represented as Störungen that not only transform one state into another, but are also greatly important psychic agents because they reveal qualities that cannot be otherwise experienced. One of the most prominent traits of the described crises is their ambiguity - it is not possible to classify them as clearly positive or definitely negative. The metaphor of awakening that suggests a sudden and complete change of one's state and an utter dissolution of the past is substituted by a metaphor of adolescence, a time of in-between which 
incorporates elements of the past and the expected future in the productive process of a creative crisis.

Wenn ich groß bin, flieg ich zu den Sternen (hereafter Wenn ich groß bin), the 1998 novel by the German author Kathrin Aehnlich, has a much simpler narrative structure than Dzimuši Latvijai, one that is typical of the childhood memory fiction genre. Childhood memories are told in chronological order; even though the narrator can be identified as a grown-up, the narration takes up the child's perspective, with only a few markers of the grown-up remembering narrator. ${ }^{15}$ The span of narrated time is longer than in Dzimuši Latvijai: it begins in early childhood and ends shortly after the narrated child turns 14 years old. Given that the interest of the present article lies in the connection between the representation of adolescence and historical and social aspects of the remembered time, only the last chapter of the novel will be analyzed. The chapter describes events revolving around the Festival of Youth Consecration, held at teaching institutions of the GDR in order to celebrate the students coming of age at 14 .

Even though the exact span of the narrated time is never concretely established in the text, it is safe to assume that it is set somewhere in the decade following the mid-sixties. The fact that this can only be assumed based on the TV shows, the athletes or the products named in the novel is remarkable - there is no mention, for example, of the events of spring 1968 which had enormous influence not only on the situation in the Czechoslovakia, but on the political climate in all socialist states in Europe. The striking absence of historical events supports an emphasis on the remembered child and the narrator's attempt to erase the remembering adult - it is hardly possible that an adult citizen of the former GDR would remember her home state in the 1960s without mentioning the aftermath of the march of Soviet tanks to Prague or the overall atmosphere in the GDR. The youthful focus of the narrative does, however, allow the exclusion of events, cultural concepts and tendencies in the society that played no role in the perception of the world for the narrated child. While the estranging perspective of the child is often used as a tool of satire (Spielman 2002: 221), the resulting effect is not satirical in Wenn ich groß bin. Rather, it counters the ruling narrative regarding the society as described and suggests an alternative story. In other words, it mildly ridicules the GDR, but does not seek to unmask

15 Since the thoughts or actions of the remembered child are never commented on or analyzed by the narrator, this text seeks to (re)construct field memories of a child. Other than in Dzimusi Latvijai, in which the process of remembering is reflected upon at least on the level of the structure, Wenn ich groß bin leaves out any meta-comments on the action of remembering or telling, thus seeking to keep the distance between the narrated child and the narrating grown-up to a minimum. 
or condemn it. It creates an image of the East German society that contests the social representation in the official memory culture of the re-unified Germany.

This re-evaluation of the GDR as a historical phenomenon must be seen in the context of its gradual integration into German historiography at large. One could say that the concept of 'two German dictatorships' has become one of the most prominent terms in contemporary studies of German history and memory culture. It incorporates the Nazi regime between 1933 and 1945 as the 'first dictatorship' and the entire existence of the GDR between 1949 and 1990 as the second. The concept of 'two dictatorships' illustrates some of the major traits of official memory culture in the reunified FRG: the division between the understanding of GDR in the so-called 'old federal states' (former FRG) and 'new federal states' (former GDR) as well as the reduction of the GDR to the negative image of an oppressive regime. Even though today's Germany is supposed to incorporate two former states into a common structure, the asymmetrical representation of their past is striking. While the FRG with its values and history is seen as the basis of today's state, the very existence of the GDR is perceived as a periodic deviation. The domination of the FRG is clearly reflected in the legal system - the 'new federal states' joined the existing FRG. The process ran according to the constitutional law of FGR, that is, no new state was formed and FGR remained the legal base of the state. The experience of 'two dictatorships' is not seen as shared by the entire German society - no one born and raised in West Germany before or after the fall of the Wall associates herself with the experience of East Germans, consequently West German identity remains unproblematized by an identification as victim or perpetrators ${ }^{16}$ of the socialist regime. The history of the GDR, on the other hand, is marginalized and mostly reduced to few qualities of the regime - especially its oppressive character - and a number of key events such as the demonstrations of 17 June 1953 and the fall of the Wall in on 9 November $1989^{17}$. Most books on German history focus on the history of the FRG while the history of the GDR is told as a detour ${ }^{18}$. In 2002, Dietrich Mühlberg bitterly admitted that the memory of East Germans "and

16 „Germany understands itself as a country that has been guilty twice because it hasn't resisted both of the large ideological Verschuldungen (means something that makes you guilty) of the $20^{\text {th }}$ century - the fascism and the communism" (Assmann 2013: 110111). Assmann also notes that East Germans are simultaneously understood as victims and perpetrators, a sentiment that is not shared by West Germans. (Assmann 2013: 115)

17 For more on the focus on the events of 9 November 1989 in the representation of the GDR in Germany's memory culture, see Tate 2011.

18 A telling example is Manfred Görtemaker's book Geschichte der Bundesrepublik Deutschland. Von der Gründung bis zur Gegenwart. Stefan Wolle notes that: "The 
their "demand of experience" do not have much in common with the official representation of their past. They are expected, to erase the biggest part of their experience from their collective memory and adhere to the „communicative and collective memory" of the other German part-society." (Mühlberg 2002: 217).

It has to be noted, however, that the representation of the GDR past in the official media of memory culture (especially museums) and art (especially cinema and literature) experienced a shift after the tenth anniversary of the fall of the Wall. Dennis Tate calls it the transition from a representation of the GDR as the Stasiland to the prevalence of Ostalgie ${ }^{19}$ (Tate 2011: 7). The first ten years after the end of the socialist regime in the GDR were marked by the debate around the Stasi and its influence on the state as well as the cooperation of the citizens with the oppressive institution. Ten years later, a new perspective on life in the GDR became visible - that of a positive remembrance of the everyday life in East Germany. In its pejorative meaning, Ostalgie is used to describe products of the GDR and their remakes that became extremely popular and commercially successful at the end of 1990's - Ostalgie is furthermore tightly associated with kitsch. Some of the most prominent signs of the growing demand of Ostalgie kitsch are the popularity of East German memorabilia including objects such as figurines of the Sandmännchen ${ }^{20}$, typical GDR furniture from the 1970's, and Trabant cars $^{21}$. Following this definition, one could assume that Wenn ich groß bin is a product of Ostalgie - the narrator's attention to detail when describing everyday objects is almost obsessive. However, the obsession with the material culture of the GDR has a distinct function in the text. The depiction of a trip to the public swimming pool details precise information regarding the prices: "Grown-ups 20 Pfennig, Children 10 Pfennig, Cabin 2 Mark, key deposit 5 Mark." (WIGB 67) Clothes are also described in detail: "(M)y swimming suit was made out of an fashionable material called Malimo" (WIGB 71) or "My mother wore a swimming suit out of Silastik with detachable plastic bra cups" (WIGB 71) etc. The obsession with prices, however, furthermore correlates to the sickly frugality of narrator's father who keeps track of all expenses, including

GDR is only mentioned sporadically on the almost thousand pages and only enters the German History with its collapse" (Wolle 2000).

19 The word 'Ostalgie' is based on wordplay, a neologism combining 'Ost' which means 'East' in German and the word "nostalgia".

20 Sandmännchen (little sandman) was the protagonist of a very popular GDR television programme for children "Unser Sandmännchen”. While original Sandmännchen from the GDR are on high demand, there is a wide range of modern Sandmännchen-products available, most of it produced not only outside of the GDR, but even outside of Europe.

21 One can, for example, book a Trabant car for a guided tour through Berlin that highlights the history of the divided city. 
such minor ones as chocolate or lemonade (WIGB 9). The fact that the narrator still remembers these details signals the constancy of her life and the complete lack of surprises or spontaneity that rules her family's life and can be easily transferred to the whole East German society whose official value was stability rather than experimentation. Another example of a careful and precise description of everyday objects is that of the portable radio the girl acquires: "I could admire the models [of radios] in the RTF-shop in our street every morning on my way to school. Stern 1, Stern 2, Stern Hobby. They all had an extricable antenna, ran on battery and could be taken everywhere." (WIGB 152) Once she buys the radio, the narrator marvels at the object: "The radio had a blue case, the grid of the speakers was white and the top part was laminated with a film that looked like wood from the distance." (WIGB 158) Only after it becomes clear that the portable radio becomes a symbol of narrator's coming of age one can understand the true reason behind such admiration for an object of obviously humble quality or beauty. As an object of such symbolic value it seems deserving such an elaborate description. Ostalgie as the reduction of GDR to exotic objects with an 'old school touch' results in a belittling representation of the GDR that lacks a critical stand. In 2000, Thomas Ahbe poignantly identified the increasing popularity of Ostalgie as a sign of the state's failing to appropriately commemorate the socialist past: "Ostalgie occurs because no professional, media-effective reworking of the GDR that would not be stigmatizing, that would be able to differentiate and balance it as well as find a contact point with people's everyday experiences, is taking place" (Ahbe 2000). Fourteen years later his argument still applies - the representation of the GDR in popular media and in official memory culture fluctuates between the two extremes of Stasiland and Ostalgie. The term Ostalgie is often falsely transferred to any kind of production - including cultural production - that focuses on everyday life in the GDR, as Dennis Tate points out (Tate 2011: 7). Thus, it would be wrong to describe Kathrin Aehnlich's novel as a piece of Ostalgie - while it clearly shows an appreciation for the material culture of the narrator's childhood and ignores the political developments in the country, it also raises questions about the strengths and shortcomings about the life in a socialist for an adolescent girl.

Katrin Aehnlich's novel is an example of a creative representation of the GDR that offers alternatives to the mainstream narrative, which reflects on the ongoing change that can be observed in Germany. The celebration of the $20^{\text {th }}$ anniversary of the fall of the Berlin Wall triggered another wave of interest in the East German past including an abundance of insightful scholarly work in different fields both inside and outside of Germany. The number of works of art treating the GDR and its history grows substantially every year, many of them 
being extremely successful in Germany ${ }^{22}$. While it cannot be expected that the history of the GDR will be treated equally to the history of the FRG in the near future, it is clear that the representation of the socialist past of the five 'new federal states' in today's Germany is gradually becoming more differentiated and open to more positive interpretations.

Similarly to Dzimuši Latvijai, irony and humour play an important role in Wenn ich groß bin, but are used in a different manner. While in Dzimuši Latvijai the narrator ironically comments on the naivete of the adolescents and the stringent, often nationalist morals of the older generation, irony becomes a tool of de-demonification of the socialist past in Wenn ich groß bin. Here, it is primarily humoristic and lacks the bitterness of Mežavilka's novel; the characters are represented as lovable, yet absurd and stereotypical. Other than concentrating on the individual experience like in Dzimuši Latvijai, Katrin Aehlich's text contributes to the scope of collective literary portraits of generations of East German childhoods. ${ }^{23}$ Wenn ich groß bin creates a detailed image of everyday life in the GDR taking an ironic stance to the experience of a socialist state that is freed of any mentionable political bondages. If the remembered child experiences any lack of freedom, it is due to her parents and not the authoritarian state. In fact, the propaganda-filled life outside the family is a liberating space for the narrator, at least as long as she believes in the contents of what she is taught. It is the bourgeois, gendered upbringing that her mother practices and the obsessive frugality of her father that suffocates the narrator's life. Her parents and not the state institutions are the source of experiences that are described as unpleasant and embarrassing or even agonizing when she is made to attend Sunday school (chapter "Wenn ich groß bin, flieg ich zu den Sternen"), take dance classes and go to a ball, or prepare inadequate costumes for the carnival (chapter "Fasching"). The narrator's first act of independent thinking is - not surprisingly - a silent rebellion against her parents that results in the choice of an astronaut-themed event in pioneers' palace instead of Sunday school. The nar-

22 One of the most obvious examples of the last years is probably Uwe Tellkamp's novel Der Turm ("The Tower") published 2008 in which the everyday reality of the GDR plays a key role. Tellkamp received the German Book Price in 2008 and German National Price in 2009 for his book. The novel has been adopted into a movie in 2012.

23 The trend of humoristic representations of "childhoods in the East" was started by the extremely popular book Zonenkinder (2002) by Jana Hensel, which can be seen as a "response" to Florian Illies' bestseller Generation Golf (2000) which depicts the everyday life of children raised in the 1980ies in the FRG. Other examples of humoristic depictions of childhood and adolescence in the GDR include but are not limited to Thomas Brussig's Am kürzerem Ende der Sonnenallee and Helden wie wir, Falko Henning's Alles nur geklaut, and Claudia Rusch's Meine freie deutsche Kindheit. 
rated child is not old enough to realize that she is choosing one system of beliefs over another and merely follows her feelings: while it is hard for her to believe in God without any physical evidence, she surely believes in the conquest of space and wants to be part of this. The girl is embarrassed by the Sunday school teacher : "She called me faithless, unteachable, not worthy to stay in this house" (WIGB 22). At the same time she is awarded the top score at the 'astronaut test' in the house of pioneers: "The pioneer [...] checked the number of stations and added the points. I was particularly fitting [for space travel]." (WIGB 31). Understandably, the narrator chooses a system that supports and cherishes her. Wenn ich groß bin suggests a flexible, pluralistic understanding of the socialist past which combines a special appreciation for the gender politics of the GDR and the simultaneous admittance of the impossibility of a socialist utopia. It must be noted that many of the negative aspects of the GDR are mentioned or at least alluded to in the novel. The most prominent of these are the poor quality of GDR products and the impossibility of travel outside of the socialist block as well as a fascination for the West, which is especially evident in the chapter "Der Hof" which describes visitors from West Germany. There are several allusions to the Stasi and to censorship, for example, when the narrator's parents prohibit her aunt from singing a Nazi song (WIGB 15) or are afraid that girl's teacher would find out about the Sunday School (WIGB 33). One of the neighbours is also described as a "Bonze", or "fat cat" - after he suddenly becomes "one from up there" (WIGB 50), meaning he either becomes associated with the party or the Stasi, other inhabitants of the house are more careful around him: "Still, precaution was demanded" (WIGB 50). These signs of the authoritarian state impact the parents of the narrated child more than they impact her life. She transgresses the order of the socialist society by adhering to capitalist values and fetishizing a commodity - a portable radio.

The title of the final chapter "Erwachsen" ("Grown-Up") is ironic - it mimics the pathos-filled speeches of teachers and parents, which surround the event described by the narrator, the Youth Consecration. On this day, the 14-years old youths are told that they are now grown-ups, with all the responsibilities towards the society that come with the new period life (WIGB 143). There is, however, no mention of any new privileges or freedoms, which one could associate with being an adult, an asymmetry that is one of the most prominent features of adolescence from a sociological point (Remschmidt 1992: 3). The holiday is planned and executed by adults only, with the adolescent having absolutely no say in any of the aspects of the festival - be it their outfits, the day's program or the guests and the menu for the festive dinner at home. Even though the festival of Youth Consecration (which the narrator experiences as a complete 
nightmare ${ }^{24}$ ) is organized by a state institution and has a clear political agenda, the narrator's family remains the primary point of perceived oppression.

The first aggravating and embarrassing experience connected to the festival is the purchase of a bra which is not yet physiologically necessary, but which seems crucial for the 'adult' young woman: "my mother didn't want to wait any longer" (WIGB 143). Her mother is supported by the other grown-up female character - the shop assistant, who sells the girl and her mother a bra of the wrong size (as smaller undergarments were not available at the time), with the explanation that the narrator "would grow into it one day" (WIGB 143). The adolescent girl is initiated into womanhood by the adult characters who ignore her unwillingness to accept the gender role that is being imposed on her. She is uncomfortable with the attributes of 'womanhood' that are physically unnecessary. The narrator feels estranged by her own body when altered by these objects: "The two cups [bra cups, filled with cotton for volume - OB] stuck out like foreign bodies. The straps pinched into my shoulders, the fastener was squeezing my back". She feels trapped and even stripped down of her human qualities: "This is how horses must feel, when they got the halter and the saddle put on them for the first time." (WIGB 144) While the narration is humorous, the metaphors of entrapment, powerlessness and foreignness are striking. Aunt Mürzel is another female adult who imposes a traditional female gender role upon the narrator: "I would be at the right age to learn the most important things in life now: cleaning, cooking, and bringing up children" (WIGB 156). It is at this moment that the narrator admits her disagreement with this division of gender roles and begins to envision a different future for herself, even if her protest is at first silent: "I was sure that she was wrong. The people of the future will not waste their time on cooking, but would buy food in tubes, the way the astronauts in space do it already" (WIGB 156). The school-taught socialist utopia of progress $^{25}$ is the only escape that is available to the teenager and she eagerly accepts it. She chooses to follow a socialist idea of womanhood a progressive working individual striving for scientific advancement. Traditional female duties such as childcare are defined as the tasks of the welfare state: "The child care will be taken over by the kindergartens, like it is done already"

24 The narrator describes the Youth Consecration as another agonizing experience that she has to participate against her will: "The anguish of the dance school ball was a good preparation of the Youth Consecration.” (WIGB 143)

25 The origin of such a future in state propaganda is clearly signalized by the words "people of the future" as well as the comparison to astronauts. In the narrated time, astronauts were one of the strongest symbols of the science-based understanding of socialist superiority. 
(WIGB 156). Even though the narrator fantasizes about an ideal future, she constructs the image of this future out of the elements available to her in reality such as the exploration of space and kindergartens. This indicates the existence of the future within the arc of the present of the socialist state, while the world of the grown-up female characters is represented as unattractive and alien. In this instance, socialist education provides the adolescent girl with an attractive alternative to the gender role that is being enforced upon her by women of older generation.

The narrator does not, however, unconditionally accept all the values of the socialist state, but rather creates an understanding of the world that incorporates elements from both socialist and capitalist systems. While the denial of traditional female role in the society is indicative of a rebellion against her mother, the clearest signal of dissent against her figure of the father is a step towards capitalist values.

The seemingly banal acquisition of a portable radio becomes first act of active - even though still silent - resistance to the full control of her parents. The radio is a symbol of freedom and independence for the narrator: "With a radio, I would be finally independent, I could take it anywhere and lie with it on the blanket by the pool" (WIGB 153). The only positive aspect of the festival of Youth Consecration is its role in achieving her goal of acquiring the necessary assets for her first considerable act of consumerism - the narrator gets most of the money needed as presents from family, friends, and neighbors. However, she does not possess the whole sum. The chance of missing the possibility of the acquisition of the desired object due to insufficient funds is the reason for her actual rebellion - the girl decides to steal from her father, whose strongest trait throughout the novel is his obsession with money and his manic frugality. It is remarkable that the narrator never experiences any feeling of guilt, but only feels the fear of being caught. After realizing that it will not happen, she subsequently enjoys the freedoms, which her new radio has, granting her:

My new life began with the portable radio. [...] I regularly stole money from my father, bought single cigarettes in the tobacco shop [...] sometimes it was enough for a bottle of beer too. I was sitting on the toilet seat, pressing the radio against the soil pipe and was waiting to finally grow up. (WIGB 159)

This sentence, the last one in the novel, describes her initial theft as the first step in a series of transgressions against the rules of family and society that the adolescent undertakes without obvious distress, suggesting the beginning of a new, more independent phase of life. 
The parents of the narrated adolescent clearly represent the petty bourgeois nuclear family that forces its system of beliefs upon their child while the socialist utopia (mediated through her school) offers her an alternative. Such an understanding is not only synonymous to the rebellion against the parents, but also against the society that imposes more stringent definition of value systems.

Even more so, the rebellion against the dominating interpretation is undertaken on two levels - on the level of the remembered adolescent who lives in a socialist state and on the level of the grown-up remembering narrator writing out of the capitalist society of the FRG. Read in terms of categories of Störung, the construction of an alternative worldview by the narrated teenager can be seen as Verstörung since the system is changed, challenged and disrupted. It is, however, not destroyed due to the ignorance of the narrator's parents who fail to perceive their adolescent daughter's transgressions. Her Verstörung of the existing order is, however, productive since it creates an attractive alternative to existing systems that are presented as insufficient and are described as foreign to the narrated girl throughout the narrative. Another example can be found in the character of great Aunt Elvira, one of the most important images of traditional female values in the book, and who gives the narrated child household items that the child obviously doesn't need yet: "Later was, when I marry and have children one day, this is what my parents decided, and Aunt Elvira prepared me with her gifts. She would give me a white damask tablecloth to every birthday and bed linen for every Christmas" (WIGB 14). Again, the child is shown as dependent upon the plans of adults and is not asked for her own opinion. The source of the household items is also important as this symbolises the traditional female role that the girl is being prepared for - the linen and tablecloths are from the mythical times of "back then": "No one ever spoke about back then in our family" (WIGB 15). However, it is clear that Aunt Elvira was affiliated with a man from the SS and still is nostalgic about the 1930's, she is once described as singing the Horst-Wessel song, the anthem of the Nazi Party: "The flag high, the ranks tightly closed. It was, as if she wanted to break the wood [of the table] with her bare hand." (WIGB 15) The child does not recognize the song, yet its meaning is clear to the reader as well as to the narrator's father: "This was, the latest instance when the father ran in and escorted the tired Aunt out of the room" (WIGB 15). The helpless, alcoholic woman is hardly an example for the narrated child, even if she is not yet aware of the ideological views of her Aunt that the narrator exposes. The narrative of the grown-up narrator who remembers her childhood and adolescence in the GDR while living in the FRG is not only a story about Verstörung, it itself can be seen as an act of Störung since it goes against the narrative that prevails in the official media of the re-unified Germany. However, the disruption achieved by this narrative can only be classified as aufstörend (causing 
BAZILEVIČA

Aufstörung) because it is part of a steadily growing corpus of comparable stories that can be incorporated into the main narrative - a process that is slowly taking place not only in literature, but also in other German media.

Even though the objects, events, and social trends constitute the background and not the main subject of the narrated stories, they inform not only the understanding of the depicted characters, but the narration as a whole - I argue that these two novels create a kind of memento mori of a world that is gone, individually and collectively. By doing so, they question the simple distinction where East is associated with socialism and negatively equated to totalitarianism whereas the West and capitalism are positively linked to democracy. The images created in the novels run against the official memory cultures into which they are inscribed and are part of a new counter-memory, despite their geographic and temporal differences.

\section{Olga Bazileviča}

Olga.Bazilevica@gmail.com

Stettiner Straße 24

13357 Berlin

DEUTSCHLAND

\section{References}

Ahbe, Th. 2000. Gruppenbild mit Banane. Aus dem Kulturalmanach des vereinigten Deutschlands. Konservative und linksliberale Meta-Erzählungen über die Ostdeutschen. - https://www.freitag.de/autoren/der-freitag/gruppenbild-mit-banane (04.12.2014).

Aehnlich, K. 2003. Wenn ich groß bin, flieg ich zu den Sternen. Berlin: Aufbau Taschenbuch Verlag.

Assmann, A. 2013. Das neue Unbehagen an der Erinnerungskultur. Eine Intervention. München: C. H. Beck.

Delfi.lv. 2013. İvāns: var vilties visā, bet ne Atmodā. - http://www.delfi.lv/news/national/ politics/ivans-var-vilties-visa-bet-ne-atmoda.d?id=43708395 (10.11.2014).

Gansel, C. 2013. Zu Aspekten einer Bestimmung der Kategorie 'Störung' - Möglichkeiten der Anwendungen für die Analysen des Handlungs- und Symbolsystems Literatur. C. Gansel, N. Ächtler, eds., Das Prinzip 'Störung' in den Geistes- und Sozialwissenschaften. Berlin, New York: de Gruyter, 31-57.

Gansel, C., N. Ächtler, eds. 2013. Das Prinzip ,Störung' in den Geistes- und Sozialwissenschaften. Berlin; New York: de Gruyter.

Jarausch, K. H. 2002. Zeitgeschichte und Erinnerung. Deutungskonkurrenz oder Interdependenz? - K. H. Jarausch, M. Sabrow, eds., Verletztes Gedächtnis. Erinnerungskulturen und Zeitgeschichte im Konflikt. Frankfurt am Main: Campus Verlag GmbH, 9-37.

Jarausch, K. H., Sabrow, M., eds. 2002. Verletztes Gedächtnis. Erinnerungskulturen und Zeitgeschichte im Konflikt. Frankfurt am Main: Campus Verlag GmbH. 
Lazda, M. 2009. Reconsidering Nationalism: The Baltic Case of Latvia in 1989. - International Journal of Politics, Culture and Society, 22. 4, 517-536.

Mežavilka, R. 2012. Dzimuši Latvijai. Riga: Dienas Grāmata.

Mühlberg, D. 2002. Vom langsamen Wandel der Erinnerung an die DDR. - K. H. Jarausch, M. Sabrow, eds., Verletztes Gedächtnis. Erinnerungskulturen und Zeitgeschichte im Konflikt. Frankfurt am Main: Campus Verlag GmbH, 217-252.

Pettai, E.-C. 2011. Memory and Pluralism in the Baltic States. London: Routledge.

Rathkolb, O., Sooman, I., eds. 2011. Geschichtspolitik im erweiterten Ostseeraum und ihre aktuellen Symptome. - Historical Memory Culture in the Enlarged Baltic Sea Region and its Symptoms Today. Göttingen: V\&R Press.

Rechtien, R., Tate, D. eds. 2011. Twenty Years On. Competing Memories of the GDR in Postunification German Culture. Rochester, N.Y.: Camden House.

Remschmidt, H. 1992. Adoleszenz. Entwicklung und Entwicklungskrisen im Jugendalter. Stuttgart; New York: Georg Thieme Verlag.

Spielman, M. 2002. Aus den Augen des Kindes. Die Kinderperspektive in deutschsprachigen Romanen seit 1945. Innsbruck: Institut für Deutsche Sprache, Literatur und Literaturkritik.

Stradiñ̌̌, J. 2014. Par akadēmisko rakstu krājumu "Latvieši un Latvija”. - Rīgas Laiks, 10, $22-26$.

Tate, D. 2011. Introduction: The Importance and Diversity of Cultural Memory in the GDR Context. - R. Rechtien, D. Tate, eds., Twenty Years On. Competing Memories of the GDR in Postunification German Culture. Rochester, N.Y.: Camden House, 1-23.

Troebst, S. 2006. Jalta versus Stalingrad, GULag versus Holocaust. Konfligierende Erinnerungskulturen im größeren Europa. - B. Faulenbach, F.-J.Jelich, eds., "Transformationen" der Erinnerungskulturen in Europa nach 1989. Essen: Klartext, 23-49.

Wolle, S. 2000. Waschputzis Wahrheit. Poesie der Erinnerung statt abstrakter Kategorien. http://www.zeit.de/2000/46/200046_dt._einheit.xml (14.12.2014).

Zake, I. 2011. Politicians versus Intellectuals in the Lustration Debates in Transitional Latvia. - E.-C. Pettai, ed., Memory and Pluralism in the Baltic States. London: Routledge, $107-131$.

Zubkova, E. 2011. Sowjetische Vergangenheit der baltischen Staaten: Schwerpunkte und Kontroverse der kollektiven Erinnerung und Geschchtsschreibung. - O. Rathkolb, I. Sooman., eds., Geschichtspolitik im erweiterten Ostseeraum und ihre aktuellen SymptomeHistorical Memory Culture in the Enlarged Baltic Sea Region and its Symptoms Today. Göttingen: V\&R Press, 89-111. 